\title{
AGAINST THE DILUTION OF A CHILD'S VOICE IN COURT ${ }^{1}$
}

\author{
Melissa L. Breger
}

Children's voices have been diluted in the court system, as the dominant paradigm in children's legal theory has too often overlooked the voices of our youth. The dilution of children's voices in the courtroom is not only disempowering and disenfranchising to children, but is also misguided. In the United States, there is no uniform standard for the role of the child's attorney. Instead there are multiple models of lawyering for children throughout the states.

This Article first examines the currently existing American child attorney paradigms through the lens of international norms and the written ideals of the CRC treaty, arguing that without the child's right to be heard codified into American law, the United States is not consonant with the United Nations Convention on the Rights of the Child (the "CRC"), Article 12. The Article then examines the laws of New York State as an additional backdrop and also to propose forwardthinking and child rights-oriented statutes.

Ultimately, this article emphasizes the fundamental importance and essence of listening to our children's true voices in the courtroom. Until children can be fully heard, their voices remain absent, or at best diluted, from the very legal system intended to help them.

1. Melissa L. Breger is a Professor of Law at Albany Law School, where she formerly served as the Director of the Family Violence Litigation Clinic. A 1994 graduate of The University of Michigan Law School, Professor Breger has dedicated her career to children and families. Her formative training occurred at The Legal Aid Society of New York City, Juvenile Rights Practice, which she refers to in this Article. Special thanks to Professor Annette Appell for her insights and her invitation to present the paper in Chicago. Thank you to Professors Leigh Goodmark, Maria Grahn-Farley, Paul Holland, Timothy Lytton, and Gary Solomon for sharing their thoughts and ideas on earlier drafts. Thank you to my fellow panelists and the engaged audience at The Law \& Society Association Annual Meeting in Chicago, IL in May 2010. I owe much gratitude to the dedicated research assistance of Melissa Arlet Gonzalez, Jennifer Sumi Kim and Rheena Haya Lomingkit. 


\section{INTRODUCTION}

As justice for children has progressively become a pivotal issue to international scholars, as well as to scholars across the United States, symposia and literature analyzing children's rights provide a wonderfully rich forum for law students, professors, and policy makers to exchange views about the rights of our most vulnerable citizens. ${ }^{2}$ Although there are myriad topics to address in the arena of children's law, the distillation at the core about a child's right to be heard is particularly timely and pertinent. The issue has been debated throughout entire journals, comprehensive books, and countless law review articles. Yet, still there has not been uniformity in United States' laws about the role of the attorney for the child, despite a growing consensus among legal academics and child advocacy experts.

The issue of hearing a child's voice is embodied in Article 12 of the United Nations Convention on the Rights of the Child (hereinafter "CRC"), which will be outlined below. The United States should draw from this aspirational CRC language in creating uniform standard roles and responsibilities for its children's attorneys. Many states have already done so, and I proffer New York State - with its more developed new laws - as one paradigm to explore further.

Ultimately, my basic premise is that the United States should have a uniform child-centered legal advocacy paradigm through which the child's views are voiced to the trier of fact as clearly as is possible. When an attorney substitutes his or her own judgment on behalf of a child, that attorney creates a barrier to the child's true voice. This is tantamount to a "dilution of the child's voice" by the time the finder of fact hears it, and it is this concept of dilution that I am utilizing throughout this Article. Admittedly, a child talking directly to a judge might be the truest way of having that child's voice being heard by the finder of fact. This type of direct contact, however, between child and judge is rare, time-consuming and fraught with many complicated ethical issues beyond the scope of this paper. ${ }^{3}$

2. One such symposium occurred at Albany Law School, examining United States laws through the lens of the CRC. In February 2009, Professor Maria Grahn-Farley convened a class of twelve students in her International Child Rights class, along with top statewide leaders, judges, scholars and practitioners. Professor Grahn-Farley invited me to write a brief essay critiquing New York laws in the context of the CRC, and that then became the genesis of this more expanded Article. Two of the most prominent and comprehensive children's law conferences in legal academia include UNLV CONFERENCE ON REPRESENTING CHILDREN IN Families CHILDREN's ADVOCACY AND Justice TEN Years AfTER FordHaM (2006) and

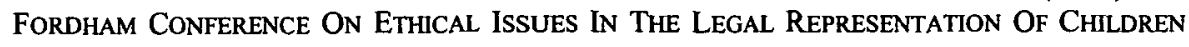
(1995).

3. As examples of the complicated issues inherent in direct judge-child contact, many jurisdictions are decreasing their use of in camera proceedings as it becomes clearer that children are indeed parties, and this would be an ex parte communication. Then, of course, there are also due process issues for the parents if the finder of fact is speaking directly to the child. See, e.g., In the Matter of H.R.C. (In re Compton), 2009 Mich App LEXIS 2558 (Mich. 
The next best alternative is to have an attorney who serves as a mouthpiece for the child and expresses a child's voice directly to the finder of fact. There is inevitably some dilution in that voice as well, as the tone, inflection, exact wording, and emotion may often be lost in translation. Yet, if an attorney adds a gloss or interpretation to the child's wishes, or worse yet, ignores the child's preferences entirely, that child's voice has been diluted at best, and possibly extinguished, in the proceedings. Even if one is not persuaded that this dilution is entirely disempowering to a child, particularly one who is most likely undergoing trauma, it is important to think about the effect on the operation of law. The finder of fact now makes a decision without hearing all positions clearly and fully articulated.

Hence, this Article makes the claim that American states should reflect upon the broad aspirational goals of Article 12 of the CRC, borrow the CRC and/or New York language as a model for formulation of uniform childcentered rules about the role of the attorney for the child, and also be cognizant of child-oriented goals in practice as well.

\section{OVERVIEW: THE UNITED NATIONS CONVENTION ON THE RIGHTS OF THE CHILD}

The CRC is arguably the most widely and swiftly ratified United Nations human rights treaty existing. ${ }^{4}$ Its history dates back to 1924 , when the League of Nations adopted a Declaration on the Rights of the Child. ${ }^{5}$ A broadened version of the Declaration was adopted by the United Nations in 1979. Then, over the course of a decade, summits were held internationally to fine-tune the wording of the treaty, which was thereby unanimously adopted in 1989 by the United Nations General Assembly.

To date, almost two hundred countries have signed the CRC, and all but two of those countries have ratified the treaty. ${ }^{6}$ Notably, the United States and Somalia are the only two countries that have not ratified the CRC.

When a country signs, but does not ratify a treaty - as in the case of the

Ct. App. 2009); Judith Cashmore \& Patrick Parkinson, What Responsibility Do Courts Have To Hear Children Voices? 15 INT'L J. OF CHILD. RTS 11-13 (2007) (addressing the issue in New Zealand and Australia). Furthermore, presumably the attorney for the child has an established relationship with the child already and should be trained in representing and interviewing traumatized children. We cannot likewise expect all judges to have relationships or bonds with all of their child litigants, nor be trained in social science literature as to the appropriate lines of questioning for traumatized children.

4. Convention on the Rights of the Child, G.A. Res. 25, U.N. GAOR, 44th Sess.61st plen. mtg., Annex, U.N. Doc. A/44/25 (1989); Maria Grahn-Farley, International Child Rights at Home and Abroad: A Symposium on the UN Convention on the Rights of the Child: I. Foreword: Crossing Borders, 30 CAP. U. L. REV. 657 (2002); CHILDREN'S VoICES: RESEARCH, Policy \& Practice 12 (Anne B. Smith et al. eds, Pearson Education New Zealand 2000) [hereinafter "Smith, Taylor \& Gollop"].

5. See Geneva Declaration on the Rights of the Child, League of Nations Doc. (1924), available at http://www.un-documents.net/gdrc1924.htm. (last visited November 11, 2010).

6. Smith, Taylor \& Gollop, supra note 4, at 12.

7. Id. 
United States with respect to the CRC - arguably that country is still bound not to contravene the treaty's object or purposes. ${ }^{8}$ Thus, to some extent the CRC retains force and legitimacy even in the United States. Some American state courts and scholars have noted that particular provisions of the CRC may eventually have the force of customary international law. ${ }^{9}$

As a whole, the CRC conveys humanitarian, economic, social, cultural, political and legal rights to the individual child, thereby allowing children's rights to parallel those of adults. ${ }^{10}$ As Professor Grahn-Farley notes:

The CRC is a unique human rights treaty, not only in its universality, but also in its paradigmatic shift from looking at the child as a passive object based on her needs to looking at the child as an active subject and bearer of her own rights ...."

8. The issue of whether a non-ratified treaty has force in a particular country is obviously a more complicated issue, which is outside the scope of this paper. I simplify the issue in keeping with the goal of this paper, which looks at the CRC for its inspirational model language and international consensus. For a more in-depth look at the issue of ratification of treaties, see, e.g., Andrew D. Finkelman, The Post-Ratification Consensus Agreements Of The Parties To The Montreal Protocol: Law or Politics? An Analysis of Natural Resources Defense Council v. $E P A, 93$ IOWA L. REV. 665, 725 ("They constrain the parties in a manner equivalent to the effect of an international agreement that the parties have signed but not ratified. In such a case, while not yet bound to perform those obligations, the parties "should [make] no efforts that would defeat the object and purpose" of the recommendations.") (citing Article 18 of the Vienna Convention on the Law of Treaties, 1155 U.N.T.S. 331, 336, and also citing Christopher C. Joyner, stating "governments ... remain obliged in spirit, if not in law, not to defeat the object and purpose of the measure, Christopher C. Joyner, The Legal Status and Effect of Antarctic Recommended Measures, in COMMITMENT AND COMPLIANCE: THE ROLE OF NON-BINDING NORMS IN THE INTERNATIONAL LEGAL SYSTEM (Dinah Shelton, ed., 2003)). See also Graham v Florida, 130 S. Ct. 2011 (2010) (Justice Kennedy dissenting) ("While international law is not decisive, it is illuminating.").

9. See, e.g., Nicholson v. Williams, 203 F. Supp. 2d 153, 234 (E.D.N.Y. 2002). Some scholars have argued that the CRC will soon be customary international law given its widespread consensus, See e.g., Gary B. Melton, Children, Family, and the Courts of the Twenty-First Century, 66 S. CAL. L. Rev. 1993, 2039-40 (1993). Professor Jean Koh Peters and her Yale Law students have compiled a comprehensive outline of all U.S. published opinions, which either view the CRC as customary international law, or cite to the CRC. Jean Koh Peters, How Children are Heard in Child Protective Proceedings in the United States and the World in 2005: Survey Findings, Initial Observations, and Areas for Further Study, 6 NEV. L.J. 966 (2006). Similarly, Professor Bernadine Dohrn outlines cases where the European Court of Human Rights and the Inter-American Court of Human Rights have incorporated and drawn upon the CRC in legal decision-making. Bernadine Dohrn, Something's Happening Here: Children and Human Rights Jurisprudence in Two International Courts, 6 NEV. L.J. 749 (2006).

10. See, e.g., Maria Grahn-Farley, International Child Rights at Home and Abroad: A Symposium on the UN Convention on the Rights of the Child: Foreword: Crossing Borders, 30 CAP. U.L. REV. 657, 659-661 (2002); Howard Davidson, A Model Child Protection Legal Reform Instrument: The Convention On The Rights Of The Child And Its Consistency With United States Law, 5 GEO. J. ON FIGHTING POVERTY 185 (1998).

11. Grahn-Farley, supra note 10, at 659. 
The CRC contains fifty-four "Articles" or sections. 12 The section of particular focus here is Article 12 of the $\mathrm{CRC}$, which says in relevant part: "States parties shall assure to the child who is capable of forming his or her own views the right to express those views freely in all matters affecting the child, the views of the child being given due weight in accordance with the age and maturity of the child."13 Article 12, subsection 2, further states: "For this purpose, the child shall in particular be provided the opportunity to be heard in any judicial and administrative proceedings affecting the child, either directly, or through a representative or an appropriate body, in a manner consistent with the procedural rules of national law." 14 Thus, the CRC values the voicing of a child's opinion or view in proceedings pertaining to the child.

Specifically, as Professor Grahn-Farley notes:

Article 12 establishes a general right of the child to participate and be heard in situations concerning the child. Article 12 is the article in the CRC that has most influenced the field of child rights to change the focus from looking at the child as an object of needs to a subject and bearer of her own rights .... To be able to develop as a human being, the child has to be heard and her opinions have to be respected .... 15

Keeping in mind any law's practical frailties and realities, ratifying the $\mathrm{CRC}$ is not necessarily consonant with implementing the CRC in practice. For example, many of the ratifying countries to the $\mathrm{CRC}$ have grappled with the issue of whether their own laws are indeed in line with the CRC both in policy and practice. ${ }^{16}$ Child's rights scholar Professor Jean Koh Peters contends that while many countries who have ratified the CRC do not in fact comply fully

12. These 54 Articles "cover Provision Rights (to have access to rights such as health care and education), Protection Rights (not to be discriminated against, nor abused), and Participation Rights (civil and political rights)." Smith, Taylor \& Gollop, supra note 4, at Introduction.

13. United Nations Convention on the Rights of the Child, adopted Nov. 20, 1989, 1577 U.N.T.S. 3, 44th Sess. 49th plen. mtg., Annex, U.N. Doc. A/44/736 (1989); 28 I.L.M. 1448 (1989).

14. Id.

15. Maria Grahn-Farley, International Child Rights at Home and Abroad: A Symposium on the UN Convention on the Rights of the Child: I. Foreword: Crossing Borders, 30 CAP. U.L. REV. 657, 659-661 (2002).

16. See., e.g., Pauline Tapp \& Mark Henaghan, Conceptions OfChildhood And Children's Voices- The Implications Of Article 12 Of The UNCRC, in Smith, Taylor \& Gollop, supra note 4, at 91-109 (noting, that at times, court practices seem slated against children's voices in New Zealand); Anne B. Smith \& Nicola J. Taylor, The Sociocultural Context of Childhood: Balancing Dependency \& Agency, in Smith, Taylor \& Gollop, supra note 4, at 1-17 (criticizing the practices of their courts in ultimately often deferring to the adults for direction in England and Australia); Edmund D. Christo, The Implementation of the United Nations Convention on the Rights of the Child in Trinidad and Tobago (July 17, 2008) (finding Trinidad and Tobago making progress toward implementing CRC into actual practice). 
with the CRC, many states in the United States actually do comply with the CRC. ${ }^{17}$ She bases this assertion upon a comprehensive study of 250 jurisdictions worldwide, which surveyed all United States jurisdictions and all signatories to the CRC. ${ }^{18}$

This Article addresses primarily the written and aspirational ideals of the $\mathrm{CRC}$ and its wide international agreement; it does not assert any argument about international compliance with the CRC. Specifically, the Article looks at current United States laws through the lens of the CRC, utilizing the CRC as "a living document to provide the framework for the development of policy and practice." 19

If children's voices are to be expressed to finders of fact based merely upon a policy, but are not expressed in reality inside the courtroom, children as a class are silenced nonetheless. ${ }^{20}$ This holds true in our United States courts as well; often there are child rights statutes on the book, but such rights are not actualized in practice. ${ }^{21}$ This Article will thus additionally examine the newest laws of the State of New York through this lens to demonstrate a state that is currently trying to close the gap between theory and practice.

\section{THE UNITED STATES DEBATE ON THE ROLE OF ATTORNEY FOR CHILD: VIEWING NEW YORK AS A WORKING MODEL}

Certainly, the United States has grappled for some time with the complicated issue of children's voices in legal proceedings. Indeed, the debate surrounding the precise role of an attorney for a child has been ongoing for decades. The issue has been written about, argued about, convened about, and analyzed extensively - yet there is still not a uniform and unanimous role nationwide.

The issue of the proper role of the child's attorney is especially salient

17. Jean Koh Peters, How Children are Heard in Child Protective Proceedings in the United States and the World in 2005: Survey Findings, Initial Observations, and Areas for Further Study, 6 NEv. L.J. 966 (2006). As one example, the United States grants lawyers for children in all juvenile delinquency proceedings. Furthermore, in many American states, children are appointed counsel in other types of proceedings.

18. Peters, supra note 17.

19. Smith, Taylor \& Gollop, supra note 4.

20. Naomi Cahn, Special Issue on Legal Representation of Children: Responses to the Conference: Representing Children and International Norms, 6 NEV. L.J. 1232, 1235 (2006) (citing Jean Koh Peters, How Children are Heard in Child Protective Proceedings in the United States and the World in 2005: Survey Findings, Initial Observations, and Areas for Further Study, 6 NEv. L.J. 966 (2006)).

21. As is noted in the First Star report with regard to United States child advocacy laws, there is not always a straight correlation between a state's law and enforcement of the law. "Our assumption is that good law is the cornerstone of any state's commitment to the rights of its children." FirSt StaR, A CHILD's Right to COUNSEl: A NATIONAL REPORT CARD ON LEgal REPRESENTATION FOR ABUSED \& NEGLECTED ChILDREN, 19 ( (nd $^{\text {nd }}$ ed. 2009), available at http://www.caichildlaw.org/Misc/Final_RTC_2nd_Edition_Ir.pdf [hereinafter FIRST STAR (2 ${ }^{\text {nd }}$ ed.)]. 
and critical in child welfare proceedings. In such proceedings, the majority of states require an attorney for the child, yet there is variance in whether that attorney plays more of an investigative role instead of an advocacy role. Child permanency or child welfare proceedings are those in which the court determines the future of a parent-child relationship and whether a termination of parental rights is necessary. These child welfare proceedings, as an umbrella category, also encompass proceedings that determine whether a parent or caretaker has committed child abuse or neglect. Different states utilize different terminology (e.g., child protective proceedings, child dependency proceedings, shelter hearings, child welfare hearings, child abuse and neglect proceedings). Fundamentally though, these proceedings are among the most critical, the most sensitive, and perhaps the most traumatic for children. It is during these proceedings that lawyers and judges determine whether a parent or caretaker has abused or neglected a child, and whether or not that parent or guardian may maintain the child in the home temporarily, and ultimately, permanently.

Much of the scholarly literature - including this Article - focuses exclusively upon the role of the attorney in child welfare proceedings as a whole, because there is little variance in the idea that an attorney must advocate for the voice of a child in juvenile delinquency or status offense proceedings. Another substantial body of literature addresses the role of the child's attorney in custody, visitation, and matrimonial proceedings. ${ }^{22}$ While there is tremendous overlap between private custody proceedings and child protective proceedings, the distinctions are significant. Child protective proceedings involve the government intervening in a family's life, as opposed to a private dispute amongst various caretakers. A child involved in the quagmire of governmental proceedings is already likely feeling fairly powerless and traumatized if removed from home involuntarily, thus making it even more essential to give the child a voice in court. ${ }^{23}$ And child protective proceedings correlate primarily with families who are impoverished or otherwise disenfranchised in American society, as discussed infra. Therefore, issues of power imbalance and caste systems are ever-present in such proceedings in our Family Courts in the United States.

22. See generally Martin Guggenheim, The AAMSL's Revised Standards for Representing Children in Custody and Visitation Proceedings, 22 J. AM. ACAD. MATRIM. LAW. 251 (2009); Linda Elrod, Client-Directed Lawyers for Children: It is the "Right" Thing to Do", 27 PACE. L. REV. 869 (2007); Randy Frances Kandel, Just Ask the Kid!: Towards a Rule of Children's Choice in Custody Determinations, 49 MLAMI L. REv. 299 (1994); Richard Ducote, Guardians Ad Litem in Private Custody Litigation: The Case for Abolition, 3 LOY. J. PUB. INT. L. 106 (Spring 2002).

23. See, e.g., Anne B. Smith et al, Children In Foster And Kinship Care, in Smith, Gollop \& Taylor supra note 4, at 73 \& 88.; Katherine Hunt Federle, The Ethics Of Empowerment: Rethinking The Role Of Lawyers In Interviewing And Counseling The Child Client, 64 FORDHAM L. REV. 1655 (1996). 


\section{A. Outlining the Various Child Attorney Paradigms in the United States}

Despite the reams of paper written on the topic, the debate concerning the role of the child's attorney perseveres. Prominent national organizations have grappled with and put forth their own model rules for attorneys for children. ${ }^{24}$ These model rules have been analyzed and dissected -necessarily for such a complicated decision -- yet still, no national consensus exists in the United States of America.

The three most prominent models in the United States describing the role of the child's attorney in child welfare proceedings are: (1) the true advocacy/counsel role, also known as the "expressed interests/wishes" model; (2) a "best interests" or guardian ad litem ("GAL") role; ${ }^{25}$ and (3) a hybrid role melding of the two. ${ }^{26}$ The hybrid model should be distinguished from some state laws, which permit two separate advocates for an individual child: one attorney and one lay advocate.

While the CRC does not explicitly posit a particular paradigm for the attorney for the child, I argue that it is most aligned with a true advocacy approach, which is addressed infra. To provide a context, I will briefly mention the principles of the dominant paradigm - the best interests model - as well as the hybrid model which attempts to meld the two constructs.

In a best interests model or GAL model, the predominant model in the United States, the child's attorney is to determine and convey to the court what is in the "best interests" of that particular child in that particular proceeding. ${ }^{27}$

24. E.g., The National Association of Counsel for Children (NACC) and the American Bar Association (ABA). The newly revised version of the ABA Proposed Model Act on the Representation of Children has language consistent with the concepts in this paper, including that once a child is capable of forming an opinion to his or her attorney, that attorney should adopt a more traditional lawyer-client relationship.

25. Technically, in some eyes, best interests lawyers and guardian ad litem lawyers are two different models - a best interests lawyer having to be an attorney, a GAL may or may not be an attorney. Yet, I am conflating the two for purposes of this Article because, like many, I see them as one and the same - a representative or lawyer who is determining "best interests" instead of conveying the voice of the child. See Jane Spinak, Simon Says Take Three Steps Backwards: The National Conference of Commissioner on Uniform State Laws Recommendation on Child Representation, 6 NEV. L. J. 1385, 1389 (2006). Additionally, some scholars have outlined up to six models, but I am grouping them into three for purposes of this Article.

26. For critique of the hybrid model, note: "But the mere expression of a child's wishes, by a lawyer who immediately turns around and undermines the child's stated position by arguing for, or presenting evidence supporting, the opposite result, hardly provides the child with a meaningful voice." Gary Solomon, Giving Children a Meaningful Voice: The Role of the Child's Lawyer in Child Protective, Permanency and Termination of Parental Rights Proceedings, available at http://www.legal-aid.org/media/68451/role\%20of\%20jrp\%20lawyer \%2010-08.pdf (referencing Merrill Sobie, Representing Child Clients: Role of Counsel or Law Guardian, 10/6/92 N.Y.L.J., 1) ("How can an attorney seriously state one position based on the child's wishes and then, without further ado, take a different and conflicting position based on his perception of the child's best interests?").

27. For a history of the guardian ad litem role and the mandates of the Child Abuse Prevention and Treatment (CAPTA) and several later modifications to it, see Child Welfare 
Yet, there is no requirement that such a lawyer listens to or even determines what that child wants. Hence, many critics would say in effect that this attorney is serving the court - or the state - more than serving his or her client, the child. ${ }^{28}$

In a hybrid model, the attorney for the child is often named the lawyerguardian ad litem, thus melding the two main paradigms into one role. As one example, the Michigan statute offers guidance about the role of the attorney in the following language: "The child's wishes are relevant to the lawyerguardian ad litem's determination of the child's best interests, and the lawyerguardian ad litem shall weigh the child's wishes according to the child's competence and maturity." 29 The hybrid attorney can often be faced with the untenable position of having to argue for a position directly inapposite to what the child client has expressed.

The best interests and hybrid models have been criticized for allowing attorneys too broad, and often unbridled, discretion in determining what is in a particular child's "best interests." 30 Some scholars have asked why the best interests of the child paradigm is dominant, asking such poignant questions such as: "(1) Are adults concerned that recognizing children's voices will erode adult power or the very institution of family? and (2) [Is it] that Family Court is involved in 'childwork' - children are the objects of concern, the

Information Gateway, About CAPTA: A Legislative History, http://www.childwelfare.gov/pubs/factsheets/ about.cfm (last visited November 11, 2010). Additionally, a detailed and thorough review of the history of CAPTA and its change to other funding schemes, see LaShanda Taylor, A Lawyer for Every Child: Client-Directed Representation in Dependency Cases, 47 FAM. CT. Rev. 605, pt. XI (A) (2009). As Professor Sarah Ramsey explains the origins of the guardian ad litem: "A major impetus for the states adopting legislation that provided for counsel for children was the 1974 Child Abuse Prevention and Treatment Act. The Act made a state's receipt of federal funds for programs under the Act contingent on the state's fulfilling certain conditions, including a requirement that the state shall: 'Provide that in every case involving an abused or neglected child which results in a judicial proceeding a guardian ad litem shall be appointed to represent the child in such proceedings. It is not clear from this requirement what role the child's representative is to play and the legislative history of the Act does not indicate what kind of representation was desired. Neither the Act nor the Department of Health and Human Services regulations require that the guardian ad litem be a lawyer." Sarah H. Ramsey, Representation Of The Child In Protection Proceedings: The Determination Of Decision-Making Capacity, 17 FAM. L.Q287, 289(1983).

28. Certainly, the issue is much more complicated and nuanced than how it is stated, but the inherent paternalism is one of the chief complaints of the best interests model. See, e.g., Martin Guggenheim, A Law Guardian by Any Other Name: A Critique of the Report of the Matrimonial Commission, 27 PACE L. REV. 785, 809, 827-28 (2007); Martin Guggenheim, How Children's Lawyers Serve State Interests, 6 NEV. L.J. 805 (2006); Barbara Glesner Fines, Pressures Toward Mediocrity in the Representation of Children, 37 CAP. U. L. REV. 411, 442 (2008).

29. Mich. COMP. LAws $§ 712 A .17 \mathrm{~d}$ (1)(i) (1939) (emphasis added).

30. See, e.g., Gary Solomon, Juvenile Rights Practice Training Manual: Vol. 1 Representing ChILdREN IN CHILd Welfare ProceEdINGs, Part Two: Role of Children's ATtORNEY (The Legal Aid Society 2009); Richard Ducote, Guardians Ad Litem in Private Custody Litigation: The Case for Abolition, 3 LoY. J. OF PUB. INT. L. 106 (Spring 2002) (addressing issue in custody cases). 
subjects of legal applications ....,31

Critics of the models also address the potential for race and class discrimination and inherent power imbalance. As Professor Randi Mandelbaum notes, while highlighting the data that the lawyers and judges in Family Court are most often of a different race, class and culture of the litigants: ${ }^{32}$

The inevitable result is that many lawyers are likely to arrive at decisions and advocate for positions on behalf of their child clients that are invariably based on what they believe to be best, based on the only value system they know, their own. Not only is there a significant chance that these decisions and ensuing positions may be against the best interests of the individual child, who is likely of a different race, ethnicity, and/or class than the legal representative, but it also leads to a system where the position taken by a child's attorney may largely be based, not on what would be best for the individual child with unique needs and values, but rather on the arbitrary chance of who was appointed to represent the particular child. ${ }^{33}$

Issues of race, ethnicity, and class in the child protective system cannot be overlooked when the city of Chicago, for example, has more than $95 \%$ of the children in foster care classified as African-American and New York City's statistics are similarly racially and economically imbalanced. ${ }^{34}$ In Central Harlem, in 1998, one out of 10 children were placed in foster care, yet fewer than 200 children total from the wealthier Upper East Side of Manhattan total were in foster care. ${ }^{35}$ Certainly, any race and class differences amongst the

31. Pauline Tapp \& Mark Henaghan, Conceptions OfChildhood And Children's VoicesThe Implications Of Article 12 Of The UN CRC, in Smith, Taylor \& Gollop, supra note 4, at 91 109.

32. See, e.g., Randi Mandelbaum, Revisiting the Question of Whether Young Children in Child Protection Proceedings Should be Represented by Lawyers, 32 LOY. U. CHI. L.J. at 36 (2000); Annette R. Appell, Protecting Children or Punishing Mothers: Gender, Race, and Class in the Child Protection System, 48 S.C. L. REv. 577, 584 (1997); Melissa L. Breger, Making Waves Or Keeping The Calm: Analyzing The Institutional Culture Of Family Courts Through The Lens Of Social Psychology Groupthink Theory, 34 LAw \& PsYchOL. REV. 55 (2010).

33. Giving the Children a Meaningful Voice: The Role of the Child's Lawyer in Child Protective, Permanency and Termination of Parental Rights Proceedings, available at http://www.legal-aid.org/media/68451/role\%20of\%20jrp\%20lawyer\%2010-08.pdf (citing Randi Mandelbaum, Revisiting the Question of Whether Young Children in Child Protection Proceedings Should be Represented by Lawyers, 32 LOY. U. CHI. L.J. 1 at $36(2000)$ ).

34. MARTIN GugGENHEIM, What'S WRONG WITH CHILDREN's Rights? 205 (Harvard Univ. Press 2005).

35. Id. (citing Dorothy Roberts, Shattered Bonds: THE COLOR OF CHILD Welfare (Basic Civitas Books 2002); Symposium, The Rights of Parents with Children in Foster Care: Removals Arising from Economic Hardship and the Predicative Power of Race: Association of 
children represented and the attorneys themselves - as well as any age and education distinctions- may not play a role at all in any approach involving the legal representation of children. Yet, if a lawyer is conveying the express wishes of a child instead of substituting the attorney's own judgment, there is much less of a chance that any variance in values enters the equation.

States that are closest to being consonant with $\mathrm{CRC}$ can become even more aligned with its Article 12 by adopting a true advocacy approach in child representation to ensure every child's voice is heard. This Article will utilize the recently enacted guidelines and laws of New York State as a case study to demonstrate the comparison between laws, and to highlight a state that is truly moving forward in the arena of child rights-oriented, child-centered statutes.

\section{B. Hearing the Child's Voice in the Direct Advocacy Paradigm: New York as an Example}

New York State has predominantly leaned toward a true or direct advocacy approach, and its statutes advise that counsel for the child "express [the child's] wishes" in, inter alia, termination of parental rights and child protective proceedings. ${ }^{36}$ A direct or true advocacy approach is one in which the lawyer's role is seen as being the child's mouthpiece and voice in the courtroom. In other words, the child's lawyer is committed to articulating and achieving the client's interests. In the direct advocacy model, children's attorneys strive to treat their child clients no differently than if they were representing an adult client, whenever possible.

Specifically, the pertinent New York statute, the Family Court Act ("F.C.A."), states:

This act declares that minors who are the subject of family court proceedings or appeals in proceedings originating in the family court should be represented by counsel .... This declaration is based on a finding that counsel is often indispensable to a practical realization of due process of law and may be helpful in making reasoned determinations of fact and proper orders of disposition. This part establishes a system of [attorneys for children] for minors who often require the assistance of counsel to help protect their interests and to

\footnotetext{
the Bar of the City of New York, 6 N.Y. CITY L. Rev. 61 (2003). Sarah H. Ramsey, Representation Of The Child In Protection Proceedings: The Determination Of DecisionMaking Capacity, 17 FAM. L.Q 287, 295-297 (1983); see also U.S. DEP'T OF HEALTH AND Human SERVICES, CHILD MaltreatMENT (1997): RePORTS From the StateS TO THE NATIONAL CHILd ABUSE AND NEGLECT DATA SYSTEM 4-5 (1999).

36. N.Y.FAM. CT. ACT $§ 241$ (McKinney 1988). See also Jane Spinak, When Did Lawyers For Children Stop Reading Goldstein, Freud and Solnit? Lessons From the Twentieth Century on Best Interests and the Role of the Child Advocate, 41 FAM. L.Q. 393, 394.
} 
help them express their wishes to the court. ${ }^{37}$

New York's system of direct advocacy child representation earned the state an overall grade of " $A$ " in a recent comprehensive national report. ${ }^{38}$ This report was revamped and updated in 2009 by First Star, a non-partisan group which evaluated each state on a series of five factors. These factors are: (1) whether counsel is provided to children in child welfare proceedings; (2) the duration of the child's attorney representation; (3) whether the attorney advocates for the express wishes of the child in a client-directed manner; (4) what education and training is required for child attorneys and whether it is multi-disciplinary; and (5) to what extent children have actual rights derived from their status as parties. The report gives "extra credit" if the state law has addressed caseload standards. Each state is then given a grade from 1-100 points with each of the five factors worth 20 points. In 2009, New York, as an example, ranked the third highest state out of the entire nation, receiving a score of 98 , an " $A$ " grade. 39

\section{Highlighting Gaps within New York's Direct Advocacy Model}

Yet, even though New York earned a stellar grade in both of the First Star reports, the role of the child advocate in New York needs to be even more precisely defined. A number of recent mandates have aided in this task. ${ }^{40}$ Most notably, in November 2007, former Chief Judge Judith S. Kaye issued Section 7.2 of the Rules of the Chief Judge, ${ }^{41}$ when she sought to clarify the role of the attorney for the child in New York. Specifically, the new Rules in relevant part, state:

37. N.Y. FAM. CT. ACT $§ 241$ (McKinney 1988).

38. First STAR, A CHILD's Right to COUNSEl: First STAR's NATIONAL REPORT CaRD ON LEGAL REPRESENTATION FOR CHILDREN ( $1^{\text {st }}$ ed. 2007), available at http://www.firststar.org/ LinkClick.aspx?fileticket=Zh0LWwpfvRA\%3d\&tabid=74 (last visited on Nov. 11, 2010) [hereinafter FIRST STAR (1st ed.)]. The $2^{\text {nd }}$ edition from 2009 rates two states with an A+, Massachusetts and Connecticut. New York still earned a grade of A in the $2^{\text {nd }}$ edition and was ranked $3^{\text {rd }}$ in the nation out of all states. FIRST STAR $\left(2^{\text {nd }}\right.$ ed. $)$, supra note 20.

39. FIRST STAR ( $2^{\text {nd }}$ ed.), supra note 20 . This amounted to 20 points in each category except for the category providing for children to be present at their own proceedings. In 2007, New York received a score of 94, also an " $\mathrm{A}$ " grade. $I d$.

40. For example, the New York State Bar Association Standards for Attorneys Representing Children in Custody, Visitation and Guardianship Proceedings were issued in June 2008; the New York State Bar Association Standards for Attorneys Representing Children in New York Child Protective, Foster Care, and Termination of Parental Rights Proceedings were issued in June 2007; the Administrative Board of the Courts of New York issued a policy statement, entitled "Summary of Responsibilities of the Attorney for the Child," in October 2007; and the Legal Aid Society, Juvenile Right Practice re-issued its practice manual policy to clarify roles in 2008.

41. N.Y.CT.RuLES $§ 7.2(2007) ; 22$ N.Y.C.R.R.. 7.2. 
[T]he attorney for the child must zealously advocate the child's position. (1) In ascertaining the child's position, the attorney for the child must consult with and advise the child to the extent of and in a manner consistent with the child's capacities, and have a thorough knowledge of the child's circumstances. (2) If the child is capable of knowing, voluntary and considered judgment, the attorney for the child should be directed by the wishes of the child, even if the attorney for the child believes that what the child wants is not in the child's best interests. The attorney should explain fully the options available to the child, and may recommend to the child a course of action that in the attorney's view would best promote the child's interests. (3) When the attorney for the child is convinced either that the child lacks the capacity for knowing, voluntary and considered judgment, or that following the child's wishes is likely to result in a substantial risk of imminent, serious harm to the child, the attorney for the child would be justified in advocating a position that is contrary to the child's wishes. In these circumstances, the attorney for the child must inform the court of the child's articulated wishes if the child wants the attorney to do so, notwithstanding the attorney's position. ${ }^{42}$

Section 7.2 of the Rules of the Chief Judge of New York also changed the title of the child advocate from "Law Guardian" to "Attorney for the Child" to ensure that the title more accurately reflected the lawyer's role as a true advocate for the child. On April 14, 2010, former New York Governor David Paterson indeed signed this change of name into law, thereby reforming

42. This language is not entirely new or entirely controversy-free, (cf. Martin Guggenheim's analysis of similar language), yet it still represents a positive step toward validating child's voices being heard by a court. It is also important to keep in mind New York State Rules of Professional Conduct states:

When a client's capacity to make adequately considered decisions in connection with a representation is diminished, whether because of minority, mental impairment or for some other reason, the lawyer shall, as far as reasonably possible, maintain a conventional relationship with the client.

Additionally, Rule 1.14(b) states that:

"[w]hen the lawyer reasonably believes that the client has diminished capacity, is at risk of substantial physical, financial or other harm unless action is taken and cannot adequately act in the client's own interest, the lawyer may take reasonably necessary protective action, including consulting with individuals or entities that have the ability to take action to protect the client and, in appropriate cases, seeking the appointment of a guardian ad litem, conservator or guardian."

N.Y. RULE OF PROF'L CONDUCT R. 1.14, available at http://www.nysba.org/Content/ ContentFolders30/CommitteeonStandardsofAttorneyConduct2/Rule1.14.pdf (last visited Nov. $11,2010)$. 
multiple statutes. ${ }^{43}$

A change in nomenclature may seem an odd way to reform a law. Yet, the term "law guardian" is reminiscent of "guardian ad litem" and served to perplex lawyers and judges. 44 As mentioned above, in many jurisdictions the guardian ad litem is often not an attorney and serves more of an investigative and reporting arm of the court. Thus, the word "guardian" in the title for the attorney for the child needed to be eliminated to better clarify the role and duties of the attorney. ${ }^{45}$

Just as when countries which have ratified the CRC do not always reflect the CRC goals in practice, even when a particular state has a codification of the role of attorney for the child, there can be variance in practice by region within that state because of the multitudinous factors involved. Illustratively, despite a direct advocacy paradigm in New York State, upstate rural regions and urban regions often differ from suburban downstate and New York City regions.

There are a number of hypotheses as to why this variance occurs. ${ }^{46}$ Some would posit that the inconsistency in practice has been the result of the amorphous term "law guardians" as discussed above. While this vagueness is most likely a legitimate factor, so are factors such as the level of training, the types of practices, accountability to an institutional provider, and the disparate cultures of Family Courts regionally. All of these factors may help to explain why attorneys for children statewide and nationwide may interpret their roles differently. 4

One prominent example of an agency singularly focused upon the true advocacy/ expressed interests paradigm is the The Legal Aid Society, Juvenile Rights Practice ("JRP") of New York City. ${ }^{48}$ JRP is the largest and one of the most respected institutional provider of legal services for children nationwide. JRP provides a system of accountability, rigorous training, and tremendous

43. Bill A7805B/S.5461-B, amending S1 101 of CPLR, SS503 \& 508 of the Executive Law; SS35 \& 35-a of the Judiciary Law; the Family Court Act, generally; SS2306 \& 2782 of Public Health law; and SS358-a, 372, 383-c, 384, 384-a, 384-b, 409-e, 409-f \& 422 of the Social Services Law (substituting the term "attorney" or "counsel" for "law guardian."), available at http://assembly.state.ny.us/leg/?default_fld=\&bn=A07805\&Summary=Y\&Actions= $\mathrm{Y} \&$ Votes $=\mathrm{Y} \& \mathrm{Memo}=\mathrm{Y} \& \mathrm{Text}=\mathrm{Y}$ (last visited Nov. 11, 2010).

44. Solomon \& Sopher, Juvenile Rights Practice Training Manual 5 (The Legal Aid Society 2009); Andrew Schepard, The Law Guardian: the Need For Statutory Clarification, N.Y.L.J., Sept 14, 2000, at 3.

45. According to the recently signed bill's summary, it "relates to the representation of children; replaces the term 'law guardian' with the term 'attorney for the child' to more accurately reflect the attomey's role." Bill A7805B/S.5461-B, available at http://assembly.state.ny.us/leg/?default_fld $=\& b n=A 07805 \&$ Summary $=Y \&$ Actions $=Y \&$ Votes $=Y$ $\& M e m o=Y \& T e x t=Y$ (last visited Nov. 11, 2010).

46. This is an area worthy of further review and research, but outside the scope of this particular Article.

47. See Melissa L. Breger Making Waves Or Keeping The Calm: Analyzing The Institutional Culture Of Family Courts Through The Lens Of Social Psychology Groupthink Theory. 34 LAW \& PSYCHOL. REV. 55 (2010).

48. Formerly Juvenile Rights Division ("JRD”). 
legal and research support. JRP also maintains a staff of paralegals, social workers and investigators as part of the team. As part of the intensive training that is mandatory for new attorneys, JRP instills in each new lawyer the ethos that the child's voice and child's wishes are the governing force behind legal representation. In 2008, JRP revamped its manual to include a thirty-six page document based solely upon the issue of child representation, which further clarifies its positions and grapples with some of the tough issues in maintaining a true advocacy approach.

\section{Grappling with Thorny Issues Arising in Direct Advocacy Paradigms}

One valid issue in children's rights law generating much discussion is how to represent a non-verbal child. Non-verbal children would be children truly not capable of clearly expressing their wishes due to age or disability, and thus their "voices" cannot be heard or conveyed to the court. Leading family law scholar and Professor Martin Guggenheim even argues that it is somewhat of a farce to have lawyers for non-verbal children, as representing such a child may encourage a lawyer to substitute his own judgment and views for that of the child's. ${ }^{49}$ Guggenheim asserts that perhaps non-verbal children are better with no attorney at all, or even a non-lawyer best interests advocate.

Across the nation to date, lawyers are appointed to children in child welfare proceedings, even if those children are non-verbal. Too often, in the case of young children, however, attorneys decide not to visit their child clients at all because they reason that the child cannot communicate. In such a case, where the attorney is not even meeting his or her client, Professor Guggenheim's position is validated.

For those who do not see the need to meet with a young child client, one must consider that there are other options and duties when an attorney for the child is appointed. As one example, JRP instructs its attorneys to study the child to assess the child's physical well-being, to examine the child's living conditions and interactions with caretakers, and to speak to collateral sources. This snapshot of the child offers a richer and more nuanced context to an attorney's legal representation, thus preventing an attorney from resorting to assumptions and choosing not to visit with a non-vocal child client simply because of the child's inability to communicate.

Similarly, scholars have argued that there are "children [who] may be too

49. See, e.g., Martin Guggenheim, A Paradigm for Determining the Role of Counsel for Children, 64 Fordham L. REv. 1399 (1996). Prof. Guggenheim states, with regards to representing very young children, "Peter Margulies, for example, wisely recommends that lawyers representing impaired elderly clients make decisions on behalf of the client by taking into account the client's lifetime commitments, where they can be determined, and the objective fairness of the various alternative decisions. It is not possible to do the same thing on behalf of clients who have no lifetime experience and have not formed, no less revealed, their values to anyone." Id. 
young to participate formally, but their age should not necessarily prohibit communication with them since 'listening to' and observing young children is possible." 50 The very young child is still entitled to a voice, and as Professor Jean Koh Peters notes, the CRC does not require that a child be mature or of a certain age. For example, even a three-year-old can assert her view that she wants to go home to her mother, and such a view should be conveyed to the court, regardless of whether it is indeed honored by the ultimate fact-finder. ${ }^{51}$ Even in Judge Kaye's mandate, attorneys must express the very young child's wishes, if the child wants the attorney to do so. ${ }^{52}$

Koh Peters posits that when attorneys are the vehicle for conveying a child's voice in the courtroom, those attorneys should limit themselves to representing the child's "legal interests" even when representing non-verbal children. ${ }^{53}$ To represent a child's legal interests is to examine the "child in her context" and investigate her unique family and personal environment, yet ultimately only proffer to the court a position which the legal proceeding has the authority to address. Specifically, a lawyer for children needs to remain cognizant and alert to the inclination to substitute personal judgment by considering questions, such as: (1) "If my client were an adult, would I be taking the same actions, making the same decisions and treating her in the same way?" and (2) "Does the representation, seen as a whole, reflect what is unique and idiosyncratically characteristic of this child?" S4 Similarly, other scholars and practitioners advocate for lawyers to spend significant time meeting with the child client in order to ascertain her unique perspective. Engaging in this process may reconcile several models of lawyering for children.

50. Anne B. Smith \& Nicola J. Taylor, The Sociocultural Context of Childhood: Balancing Dependency \& Agency, in Smith, Taylor \& Gollop, supra note 4, at 14 (citing Pugh and Selleck , Listening to and Communicating with Young Children in the Voice of the Child: A Handbook for Professionals 120-136 (Falmer Press, London 1996) ("Also, participation by children helps them to accept the decision made about them." Id.).

51. Jean Koh Peters, Special Issue on Legal Representation of Children: Article: How Children are Heard in Child Protective Proceedings in the United States and the World in 2005: Survey Findings, Initial Observations, and Areas for Further Study, 6 NEV. L.J. 966 (2006).

52. In fact, Rule 7.2 is silent on the age issues. N.Y.CT.RuLES, $\S 7.2$ (2007); N.Y. CoMP. CODES R. \& REGS. TITLE 22, $\S 1200.14$. Many argue that seven be the bright line because children as young as seven can be charged with juvenile delinquency. JRP (and the new standards of the New York State Bar Association) propose following the wishes of children as young as seven for several developmental reasons, and also because seven-year-old children in many states can actually be charged with juvenile delinquency. For another perspective, see Professor Donald Duquette, Two Distinct Roles/Bright Line Test, 6 NeV.L.J. 1240 (2006) (arguing for a bright-line distinct role).

53. Jean Koh Peters, The Roles and Content of Best Interests in Client-Directed Lawyering for Children in Child Protective Proceedings, 64 FORDHAM L. REV. 1507, 1511 (1996).

54. Id.

55. See, e.g., AnN M. Haralambie, The Child's AtTorney: A Guide to RePresenting Children in Custody, Adoption and Protection Cases (Family Law, American Bar Association 1993). 
As a concrete example of this process, the lawyer for the child is not expected to follow blindly any statement asserted by a child, but rather to delve into the nuances of what the child is saying to help the child determine her true wishes. ${ }^{56}$ Critics of a true advocacy model talk about how children are often coached, or worse yet, alienated against one parent. The lawyer needs to counsel the child as she would any other client. If a child were to say "I want to live with my parents" - this could be absolutely the truth at face value, but it could also be said through layers of complexity: "I don't want to live in foster care" or "My parents promised me I wouldn't have to go to school, if I told you that" or "I feel guilty speaking against my parents." These are valid explanations on their own, but the attorney for the child would best inquire further about why a child is making a particular request to ascertain her true voice. Then, as in Judge Kaye's mandate, the attorney can counsel the child as to her options - - careful to keep in mind the power imbalance between attorney and client, adult and child. In the final analysis, the attorney should express the child's whole voice to the court, as the attorney would do for any other client within the context of a lawyer's role and professional responsibilities.

Critics of a true advocacy approach additionally argue that children often vocalize positions, which then place them in harm's way. Yet, these critics need to be mindful that checks and balances already exist in our child welfare system. ${ }^{57}$ In other words, the attorney for the child in a court proceeding is just one voice of many in a child welfare proceeding and is not necessarily the determinative voice. The Family Court Judge will hear from the agency and caseworker and the parents' attorneys. Perhaps the judge will also hear from a mental health professional, educational professional, and/or CASA volunteer. After hearing the voices of all attorneys, advocates, and litigants, the Court ultimately makes the final determination upon assessing all voices. ${ }^{58}$

A child has a right to be heard in the proceeding just as any other litigant, particularly because it is the child's life which is arguably impacted the most by any resultant decision in the proceeding. And if we listen to children on this very issue, many children would choose not to have a lawyer at all rather than have one who does not express their true voices. ${ }^{59}$

56. The NACC rules state: "Client directed representation does not include "robotic allegiance' to each directive of the client." NATIONAL ASSOCIATION OF COUNSEL FOR CHLDREN, REVISED VERSION OF ABA STANDARDS OF PRACTICE FOR LAWYERS WHO REPRESENT CHILDREN IN ABuse AND Neglect CASES B-4 (1999).

57. FIRST STAR ( ${ }^{\text {st }}$ ed.), supra note 37 ("Client-directed representation empowers the court to make the most prudent and wise decision as to the best interests of the child").

58. See e.g., Robert E. Shepherd, Jr. \& Sharon S. England, I Know the Child Is My Client, But Who Am I?, 64 FORDHAM L. REV. 1917 (1996). Rarely are juries utilized in such proceedings nationwide. For an analysis of the use of juries in child protective proceedings, see Melissa L. Breger, Introducing the Construct of the Jury Into Family Violence Proceedings and Family Court Jurisprudence, 13 MiCH. J. GENDER \& L. 1 (2006).

59. We should not underestimate the effect of having a voice through an attorney can have on a child, in terms of that child's sense of empowerment but also in terms of adhering to and permanency of orders. See infra note 62 and accompanying text. As Professor Guggenheim 
Thus, if an attorney for the child substitutes his or her own judgment or opinion, that attorney imposes a barrier between the court and the child's voice and creates even more dilution to the child's true voice. This is disempowering to children who are already disenfranchised and silenced for various reasons, such as class, race, age, and status in society.

\section{Recognizing A Child's Voice As A Meaningful Component Of Legal Decision-Making}

Children's voices have been stifled, diluted or ignored in the court system, and this is partly due to the dominant paradigm in children's legal theory focusing upon "best interests," while often overlooking the voices of our youth. The dilution of children's voices in the courtroom is not only disempowering and disenfranchising to youth, but is also misguided.

The complexity and nuance of the concept of a child's voice in the courtroom, particularly as it relates to children's rights and justice, is beautifully articulated by leading critical child-centered theorist, Professor Annette Appell: "Children's voices should inform and guide justice, but its variety, softness and youth easily confound that goal. Children are extraordinarily diverse and each child inhabits multiple roles ...."60 In representing children, Appell goes on to urge that:

[F]inding and respecting a child's voice means doing our best as adults and professionals to mute our voices. That means doing our best not to project our class, race, gender and professional orientation or values onto our clients and their dilemmas ... . We must have faith in their wisdom and their identity as far away from our own wisdom and identity as our

states: "[C]hildren have contacted me periodically complaining about their law guardian. Their complaints are strikingly similar. They all told me that they wanted a lawyer who would fight for them... if they could not have a lawyer who could seek what they want, they would much prefer not having a lawyer at all...the core meaning of a lawyer in American culture is dramatically at odds with the role and purpose of a law guardian." Martin Guggenheim, $A$ Law Guardian by Any Other Name: A Critique of the Report of the Matrimonial Commission, 27 PACE L. REV. 785, 805-806; see also Theresa Hughes, A Paradigm Of Youth Client Satisfaction: Heightening Professional Responsibility For Children's Advocates, 40 CoLuM. J.L. \& Soc. ProBs. 551 (2007); Erik Pitchal, Children's Constitutional Right to Counsel in Dependency Cases, 15 TEMP. POL. \& CIV. RTS. L. REV. 663 (Summer 2006); Jaclyn Jean Jenkins, Listen to Me! Empowering Youth and Courts Through Increased Youth Participation in Dependency Hearings, 46 FAM. CT. REV. 163 (2008); Miriam Aroni Krinsky and Jennifer Rodriguez, Giving a Voice to the Voiceless: Enhancing Youth Participation in Court Proceedings, 6 NEV. L. J. 1302 (2006); cf. Emily Buss, Confronting Developmental Barriers to the Empowerment of Child Clients, 84 CORNELL L. REV. 895 (1999).

60. Annette R. Appell, Special Issue on Legal Representation of Children: Article: Children's Voice and Justice: Lawyering for Children in the Twenty-First Century, 6 NEv. L.J. 692, 713 (2006). 
clients may be. ${ }^{61}$

In a true advocacy paradigm, a lawyer's role is certainly not to merely parrot the child's voice in the courtroom and end there. As in any other clientdirected advocacy paradigm, a lawyer is also a counselor and adviser of the panoply of options to a client.

As is the case in many Family Court cases, procedural justice is critical to all litigants; ${ }^{62}$ the fairness of the processes themselves often weigh more importantly than the result in determining a litigant's sense of justice. In this regard children should be allowed to voice their opinions about matters which involve their own lives. ${ }^{63}$ Children need to be meaningfully engaged in the legal processes themselves, not just the outcomes or enforcement.

61. Id. at 715 .

62. See, e.g. Melissa L. Breger, Gina M. Calabrese, and Theresa A. Hughes, Teaching Professionalism in Context: Insights from Students, Clients, Adversaries and Judges, 44 S.C. L. REV. 303 (2004); Melissa L. Breger, Introducing the Construct of the Jury Into Family Violence Proceedings and Family Court Jurisprudence, 13 MicH. J. GENDER \& L. 1, 2(2006). See also, Miriam Aroni Krinsky and Jennifer Rodriguez, Giving a Voice to the Voiceless: Enhancing Youth Participation in Court Proceedings 6 NEV. L. J. 1302 (2006).

63. See, e.g., Bernard P. Perlmutter, George's Story: Voice and Transformation Through the Teaching and Practice of Therapeutic Jurisprudence in a Law School Child Advocacy Clinic, 17 ST. THOMAS L. REv. 561 (2005) ("Even when the hearing outcome is negative, people treated fairly, in good faith, and with respect, experience greater satisfaction with the result and are more likely to comply with the decision rendered by the court...they may even feel they have voluntarily chosen the course that is handed down by the judge. These feelings of 'voluntariness' rather than coercion tend to produce greater compliance with the results of the hearing. In observing how George was often treated by his caregivers and the many decisionmakers who exercised dominion and control over his life both before and after our Clinic was appointed as his attorney ad litem, our students noted how excluding him from the process, without first giving him opportunity to heard, denied him both voice and validation."); Anne B. Smith \& Nicola J. Taylor, The Sociocultural Context of Childhood: Balancing Dependency \& Agency, in Smith, Taylor \& Gollop, supra note 4, at 13 (citing P. F. Tapp, Use of the United Nations Convention on the Rights of the Child in the Family Court, in PROCEEDINGS OF THE FAMILY LAW CONFERENCE 235-264 (Family Law Section of the New Zealand Law Society 1998).

64. While outside the scope of this particular Article, I would argue that children's law is lagging and is an outlier to the progressive developments in other areas of law, such as mental disability and elder law, which are trending toward pure advocacy even when clients have limited capacity. I thank my Albany Law School colleagues, particularly Professors Evelyn Tenenbaum, Nancy Maurer and Tim Lytton, for raising these issues when I presented this paper at an Albany Law School Faculty Workshop. Specifically, there are similar issues representing the elderly and that NY's Section 81 Mental Hygiene Law "functional competence" laws have reconciled some of these issues, as well as parallels in the areas of disability rights and clients with " diminished capacity. See also Martha Minow, Children's Rights: Where We've Been, And Where We're Going, 68 TEMP. L. REV. 1573, 1579 (1995) (even those in comatose states arguably have self-determination rights). 


\section{CONCLUSION: SYNTHESIS OF UNITED NATIONS AND UNITED STATES LAWS}

The widespread ratification of the CRC represents an international consensus view that children should have a voice in their own proceedings. ${ }^{65}$ This Article is not specifically positing that the United States ratify the CRC treaty - although ratification would certainly be a positive movement-but rather that the United States uniformly embrace the aspirational goals of the CRC Article 12 and the international norm. Focusing more closely upon the jurisdictions within the United States, this Article offers the laws of the State of New York as one positive example. New York is close to meeting the CRC mandate that children have "the right to express [their] views freely." All states, including New York, need to ensure that the legislative ideals are implemented statewide in a consistent and mandatory fashion so that children's voices are as unfiltered as possible.

By contrasting laws in the United States to the ideal language of the CRC, I hope to highlight the fundamental importance and essence of listening to our children's voices in the courtroom, as leading scholars have been urging for decades.

We should strive to enact a uniform standard nationwide. Specifically, other states in the United States should follow New York State's lead in developing a true advocacy approach to hear children's express wishes and voices in the courtrooms with all their depth and complexity. Only then can the United States as a country accurately align itself with the international consensus embodied in Article 12 of the United Nations Convention on the Rights of the Child and be truly compatible with the child's right to be heard. Children's voices must be heard, and every client, even a young child, deserves nothing less. Until children can be fully heard in court, their voices remain absent, or at best diluted, from the processes of the very legal system intended to help them. 